Research Paper

\title{
Hydrographic Characteristics of a Coastal Antarctic Transect in the Indian Ocean Sector
}

\author{
ALVARINHO J LUIS* and VINIT R LOTLIKAR \\ Earth System Science Organization (ESSO), National Centre for Antarctic and Ocean Research (NCAOR), \\ Headland Sada, Goa 403 804, India
}

(Received on 07 June 2016; Accepted on 29 November 2016)

\begin{abstract}
We address results of the hydrographic measurements obtained from Expendable CTD (XCTD) probes deployed along a coastal Antarctic transect between Prydz Bay and India Bay during austral summer of 2013. The thermal structure indicated two upwelling zones: one centered at $38^{\circ} \mathrm{E}$ and another at $60^{\circ} \mathrm{E}$; these entrain Circumpolar Deep Water (CDW) to shallow depths. The two bays are influenced by cyclonic circulation adjacent to the Amery Ice Shelf and in the Weddell Sea. The former promotes a cold front at $70^{\circ} \mathrm{E}$ which extends to deeper depths, while the latter promotes a cold front at $40^{\circ} \mathrm{E}$ in the upper $400 \mathrm{~m}$. We encountered deep mixed layer $(>100 \mathrm{~m})$ in low weak wind speed condition. The temperature and salinity profiles capture signatures of super cooled water in the Prydz Bay between 90-164 m and Antarctic Bottom Water at deeper depths (>900m). CDW is the voluminous water mass detected in the study area. The research work, which is first of its kind pertaining to the coastal Antarctic sector by deploying XCTDs, will serve as benchmark for planning a detail survey in this region using a dedicated research vessel for deeper penetration of hydrographic recording instruments for a broader and 3-dimensional picture of the circulation and water mass transformation.
\end{abstract}

Keywords: XCTD Observations; Water Masses; Thermohaline Structure; Mixed Layer Depth; Coastal Antarctica

\section{Introduction}

The Southern Ocean (SO) has a profound influence on the world's ocean and the global climate system (Deacon, 1937). It connects global oceans and acts as a major conduit for ocean circulation (Rintoul et al., 2001; Iudicone et al., 2008). The Antarctic Bottom Water (AABW), which is one of the most important water masses of the global ocean, is formed at a few regions of the Antarctic shelf. AABW descends the shelf and flows northward, together with the Antarctic Intermediate Water and the Lower Circumpolar Deep Water, both of which are generated within the SO. They constitute the counter-clockwise part of the Meridional Overturning Circulation (MOC) and have significant effects on the ventilation and heat transport at abyssal and intermediate depths of the world's oceans. The southward flux of the MOC is driven by the North Atlantic Deep Water (NADW).
The dense AABW, which refers to several varieties of bottom waters produced and exported around the Antarctic continental margins, is generated around some areas of the Antarctic shelf (Orsi et al., 1999; Gordon et al., 2004). The different varieties of bottom waters are the Weddell Sea Bottom Water formed in the Weddell Sea, the Ross Sea Bottom Water formed in the western Ross Sea, and the Adélie Bottom Water formed along the Adélie coast of Wilkes Land (Orsi et al., 1999, 2002). AABW formation is rather complicated as it involves poorly understood shelf processes and mixing of different water masses (Gill, 1973; Foster and Carmack, 1976). During austral winter, sea ice is formed within the Antarctic coastal polynyas due to convection facilitated by cold and strong offshore winds (Arrigo and Van Dijken, 2003), leaving behind high salinity dense water (brine). The brine sinks, driving deep convection bringing water with high nutrients and $\mathrm{CO}_{2}$ to the surface (Arrigo et al., 2008). Finally, on

*Authorfor Correspondence: E-mail:alvluis@ncaor.gov.in; alvluis1@gmail.com 
Antarctic shelf, the Circumpolar Deep Water (CDW) mixes with younger waters of local origin, producing ventilated water which is known as Modified Circumpolar Deep Water (mCDW; Withworth et al., 1998). It is injected into mid-depths and contributes to the formation of the different types of AABW. Sea ice formation within the Antarctic shelf converts local upper waters like the Antarctic Surface Water (AASW) or the shoaling mCDW into the densest Shelf Water (SW) (Whitworth et al., 1998). The SW is divided into Low Salinity Shelf Water (LSSW), and High Salinity Shelf Water (HSSW), which are discriminated by salinity of 34.6 psu (Smith et al., 1984). The HSSW is recognized by its core salinity of $\sim 34.8$ (Orsi et al., 2002).

The region between the eastern limb of the Weddell Sea and western edge of the Prydz Bay (black contour labeled by letter 'A' in Fig 1) is the focus of this study because of the following reasons: (i) this region is the site of an important confluence between the region west of Weddell-Enderby Land, Kerguelen Plateau to the north and the AustralianAntarctic Basin to the east. As a consequence, the resulting signature of water masses, circulation and biogeochemistry of this area is significantly influenced by this confluence. (ii) The Prydz Bay has been widely suggested as a region for AABW formation (Jacobs and Georgi, 1977; Orsi et al., 1999; Yabuki et al., 2006), thereby meriting a investigation of hydrographic features and the role of adjacent cyclonic circulation in the Weddell Sea and circulation adjacent to the Amery Ice Shelf on vertical thermohaline structure. The oceanographic features are cursory in the region from $10^{\circ}$ to $77^{\circ} \mathrm{E}$, so we address the water masses distribution and thermohaline structure during the austral summer period of 2013. The hydrographic data was collected using eXpendable CTD (XCTD) probes deployed during the Indian Scientific Expedition to Antarctica. Though the results are preliminary in nature, they help to gain insight into the oceanographic features of the study area, as well as in facilitating the development of sampling strategy using a dedicated oceanographic vessel in the near future.

\section{Oceanographic Features of the Study Area}

The study area extends from $9.55^{\circ} \mathrm{E}$ to $76^{\circ} \mathrm{E}$, from India Bay, the berthing site which is about $100 \mathrm{~km}$ north of the Indian Research base Maitri to Prydz
Bay (the region marked by letter ' $A$ ' in Fig. 1). The region lies inside the Weddell-Enderby basin, with the Kerguelen Plateau to the north-east and the shallowest point of the Princess Elizabeth Trough (PET) to the east of Prydz Bay. The survey area can broadly be divided into two regimes: the region west of $50^{\circ} \mathrm{E}$, which is dominated by the eastward extension of the Weddell Gyre (Gordon, 1998; Park et al., 2001), while to the east of $50^{\circ} \mathrm{E}$, the Antarctic Circumpolar Current (ACC) and its southern fronts, comprising southern ACC front (sACCF) and Southern Boundary (SB) (Orsi et al., 1995), influence the region from the north. The fronts are forced southward by the Kerguelen Plateau, and flow eastward through the PET. The Amery Ice shelf is also an important feature, feeding shelf and ice-shelf water into the study region.

Two important features that are identified at the margin of Antarctica are the Antarctic Slope Front

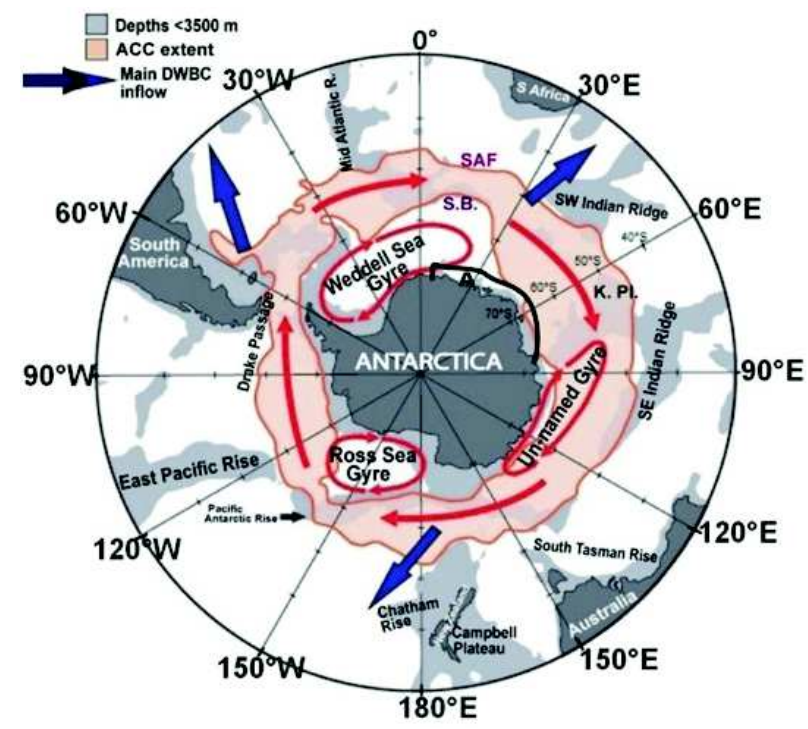

Fig. 1: The main oceanographic elements of the Southern Ocean including: (i) the ACC contained by the Subantarctic Front (SAF) and southern limit of southern boundary (SB) or Upper Circumpolar Deep Water; (ii) the Ross, Weddell and unnamed subpolar gyres; and (iii) the main exit points of deep western boundary currents from the Southern Ocean (deep blue arrows). The general path for the ACC is from Orsi et al. (1995) with modifications based on Heath (1985) and Morris et al. (2001). The coverage of the XCTD sampling area lies within the black contour indicated by letter ' $A$ '. Bathymetric elevations are Annotated as R - ridge; and K. PI.- Kerguelen Plateau. The base chart is modified from Orsi and Whitworth (2005) 
(ASF) and the Antarctic Coastal Current (ACoC). The ASF defines the boundary between cold, relatively fresh waters encountered at the Antarctic continental shelf and the warmer, more saline waters farther offshore, which are found below the near-surface layer (Jacobs, 1991). It is associated with a westward transport around Antarctica, which is considered be a consequence of the prevailing westward winds near the Antarctic continent, which induce an Ekman transport of cold, relatively fresh surface water toward the continent, thereby setting up a geostrophic westward flow around Antarctica (Deacon, 1937; Sverdrup, 1953). This flow is constrained to the continental slope depths of 500-1000 on the eastern side of the Antarctic Peninsula (Muench and Gordon, 1995). The ACoC is a fast, shallow flow over the continental shelf, which is often associated with the front of the ice shelf (Jacobs, 1991). The transport of the ACoC, and that associated with the ASF, is important for the advection of nutrients and krill, for preconditioning the shelf waters for the formation of AABW through their associated heat and freshwater fluxes, and for supplying waters beneath ice shelves, thus melting the underside of the ice shelf (Heywood et al., 2004).

In the Indian Ocean sector, negative wind stress curl associated with the Antarctic Divergence promotes cyclonic oceanic sub-structure. Zeverev (1963) reported the presence of a series of cyclonic gyres between $20^{\circ}$ and $100^{\circ} \mathrm{E}$, while Smith et al. (1984) showed that the subsurface cyclonic eddies of $500 \mathrm{~km}$ diameter were located at $67^{\circ}$ and $80^{\circ} \mathrm{E}$, along $65^{\circ} \mathrm{S}$. Other researchers reported the presence of cyclonic eddies at $67^{\circ}, 100^{\circ}$, and $115^{\circ} \mathrm{E}$, and the zonal diameter of the eddies was estimated to be about $500 \mathrm{~km}$ (Wakatsuchi et al., 1994). In the present study area, the Antarctic Divergence is located relatively close to the continent and some stations are placed hundreds of kilometers away from the coast, and so the topographic features of the continental shelf and slope could influence the water mass properties (Wakatsuchi et al., 1994).

\section{Data Processing}

The XCTD deployments were carried out from $19^{\text {th }}$ $25^{\text {th }}$ February, 2013 (Fig. 2), from the Indian Antarctic Expedition vessel M V Ivan Papanin plying between Prydz Bay and India Bay. The hydrographic stations

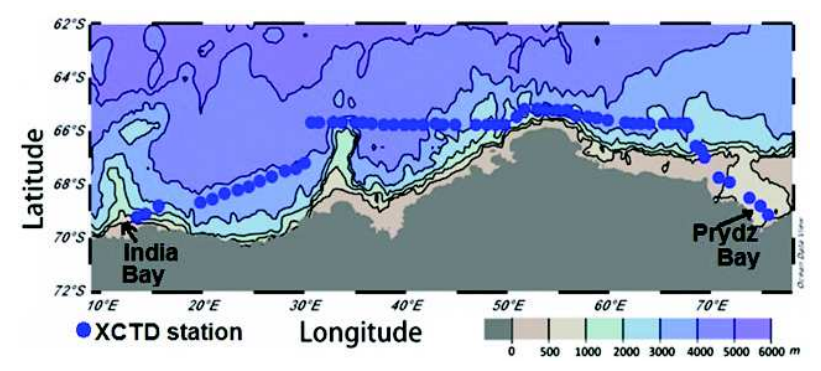

Fig. 2: The XCTD sampling locations during $19^{\text {th }}-25^{\text {th }}$ February, 2013. The bathymetry is shown in the background

were spaced 30-32 nautical miles apart. The XCTD probes (make: Tsurumi Seiki Company Limited, Japan; type: XCTD-3; terminal depth: $1000 \mathrm{~m}$; temperature/ salinity accuracy: $\left.\pm 0.02{ }^{\circ} \mathrm{C} / \pm 0.03 \mathrm{mS} \mathrm{cm}^{\prime \prime}\right)$ were deployed at every degree longitude to record temperature and salinity in the upper $1 \mathrm{~km}$ of the ocean. A comparison of the XCTD-3 data and Sea Bird CTD profiles reveal that the former is consistent with temperature and salinity accuracy specified by the manufacturer (Mizuno and Watanabe, 1998), and that the fall rate for the XCTD probes show no systematic bias in the fall equation provided by the manufacturer (Kizu et al., 2008). The temperature profiles were quality-controlled by following the standard procedures (Bailey et al., 1993; Uchida et $a l ., 2011)$. High frequency noise in the salinity profiles was minimized by using a median filter with a $15-\mathrm{m}$ (Xiaojun et al., 2004). We also used ECMWF interim daily for quantifying the net heat flux at surface and surface wind speed (Berrisford et al., 2011)

\section{Results}

Criteria used in this study to identify the water masses in the coastal Antarctic domain are listed in Table 1. The most important of these are Antarctic Surface water (AASW), Circumpolar Deep Water (CDW) and AABW. The Winter Water (WW) is one of the components of Antarctic Surface Water (AASW), the other being Summer Surface Water (SSW). WW, which forms a temperature minimum layer below the $\mathrm{SSW}$, is characterized by temperature of $-1.87^{\circ} \mathrm{C}$ and salinity of 34.34. It is a remnant of the surface water formed by winter convection (Wong et al., 1998), which spreads northwards by winds away from the continent. SSW has a temperature $<4^{\circ} \mathrm{C}$ and the salinity range of 33.5 to $34 \mathrm{psu}$. These water masses 


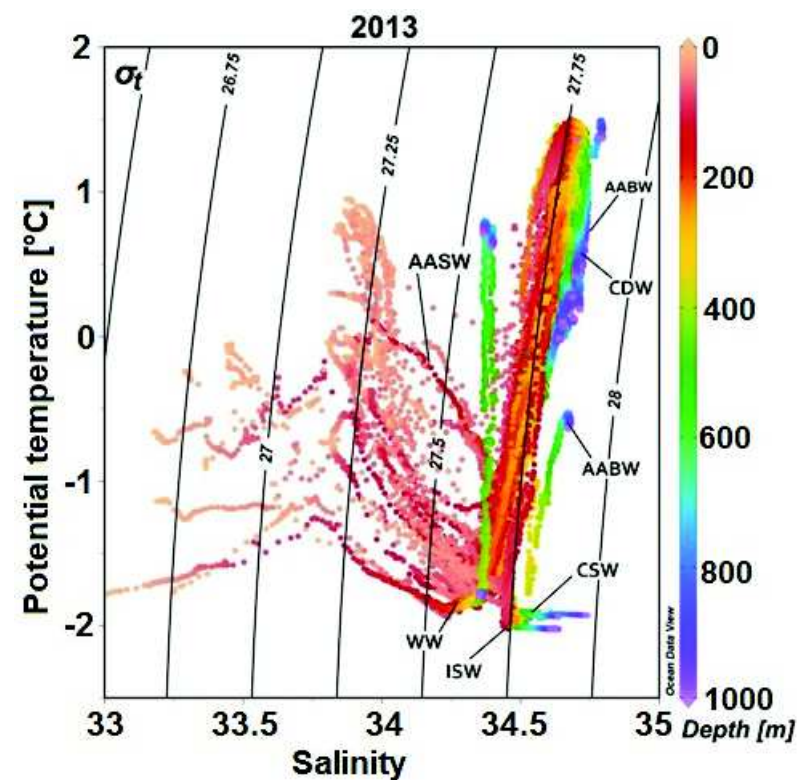

Fig. 3. $\theta-S$ diagram prepared using the XCTD data collected during period $19^{\text {th }}-25^{\text {th }}$ February, 2013

are representative of freezing and melting in the study area. Winter mixed layer are usually remnant of the previous winters. WW is usually under-saturated due to non-conservative processes of organic matter in surface layer and entrainment of warm CDW water into mixed layer during winter when sea ice cover mitigates the wind effect.

Below WW, the Continental Shelf Water (CSW) $\left(\theta:-1.85^{\circ} \mathrm{C}\right.$ and salinity: $\left.34.56 \mathrm{psu}\right)$ was detected in the Prydz Bay. CSW is relatively salty and denser than the surface waters and is found in the subsurface region. Mixing over the shelf occurs throughout the water column unlike in the open sea. Convection supports sea ice formation and brine rejection leading to the genesis of these cold saline waters. The voluminous water mass in the study area is $\operatorname{CDW}(\theta$ : $0.61{ }^{\circ} \mathrm{C}$ and salinity: $34.68 \mathrm{psu}$ ). It is involved in the formation of all other water masses through vertical and lateral mixing induced by polar easterlies at the Antarctic slope and shelf regions (Whitworth et al., 1998). This high saline warm water is driven from the sub-Antarctic region to the Antarctic region, where it keeps the region ice free during winter.

The CDW was detected below $75 \mathrm{~m}$, between $32^{\circ}$ and $42^{\circ} \mathrm{E}$, and at a deeper depth $(>180 \mathrm{~m})$ between $58^{\circ}$ and $68^{\circ} \mathrm{E}$ (Fig. 4). Our profiles captured traces of AABW at deeper depths $(>900 \mathrm{~m})$, which is probably due to truncation of the profiles at $1000 \mathrm{~m}$. Previous time series study carried out using portable CTD data during 24-27 February, 2006 could not detect either CDW or AABW in this region (Anilkumar et al., 2010). Supercooled water having temperature and salinity ranges of -2.14 to $-1.96^{\circ} \mathrm{C}$ and 34.39 to 34.46 , respectively, have been detected in the region north of the Amery Ice Shelf (Shi et al., 2011). These are caused by melting beneath the sea ice where the freezing point is very low due to high pressure (Shi et al., 2010). From Fig. 4 the signatures of the supercooled water was found in the Prydz Bay at $70.9^{\circ} \mathrm{E}$, between $90-167 \mathrm{~m}$, at $71.8^{\circ} \mathrm{E}$, between 99 $139 \mathrm{~m}$, and at $73.7^{\circ} \mathrm{E}$, between $123-164 \mathrm{~m}$.

In the Prydz Bay, up-sloping of isohalines and presence of low temperature $\left(<0{ }^{\circ} \mathrm{C}\right)$ densest water $>27.7 \sigma_{\mathrm{t}}$ at surface are detected (Fig. 4). The melt water is contributed by the Amery Ice Shelf and three glaciers located nearby the Larsemann Hills, viz. Fisher $\left(\sim 75^{\circ} \mathrm{S}, 65^{\circ} \mathrm{E}\right)$, Lambert $\left(\sim 73^{\circ} \mathrm{S}, 70^{\circ} \mathrm{E}\right)$ and Polar Record glaciers $\left(\sim 70^{\circ} \mathrm{S}, 7^{\circ} \mathrm{E}\right)$ (Anilkumar et $a l, 2010)$. The fresh water which is marked by low salinity $(<34)$ in the upper $30 \mathrm{~m}$ pushes the high salinity dense water below $50 \mathrm{~m}$ (Fig. 4). The winter time observations of Middleton and Humphries (1989) indicate that the Prydz Bay shelf is occupied by water of salinity slightly higher than 34.6 psu, the minimum salinity required for the formation of AABW. Our section provides an evidence for shelf water descending down the continental slope to deeper depth (Fig. 4).

The mixed layer depth (MLD) varies from 20 $\mathrm{m}$ at $15.6^{\circ} \mathrm{E}$ to $122 \mathrm{~m}$ at $50^{\circ} \mathrm{E}$. The deepening of the MLD is found to be unrelated to the surface wind speed or net heat flux. The deeper MLD on the eastern side of the transect can be attributed to large influx of fresh water from adjacent Amery Ice Shelf and glaciers, which forms a thick layer at the surface. On the other hand, intrusion of cold and fresh water from the Weddell Sea is evident in the temperature and salinity structure on the western side of the transect. The wedge structure in the temperature isotherms up to $40^{\circ} \mathrm{E}$, where it forms a strong thermal front, is interrupted by the upwelling CDW; it is a clear indication of the confluence of Weddell Sea circulation with the study area. Likewise, three stations in the Prydz Bay capture a front at $70^{\circ} \mathrm{E}$, 

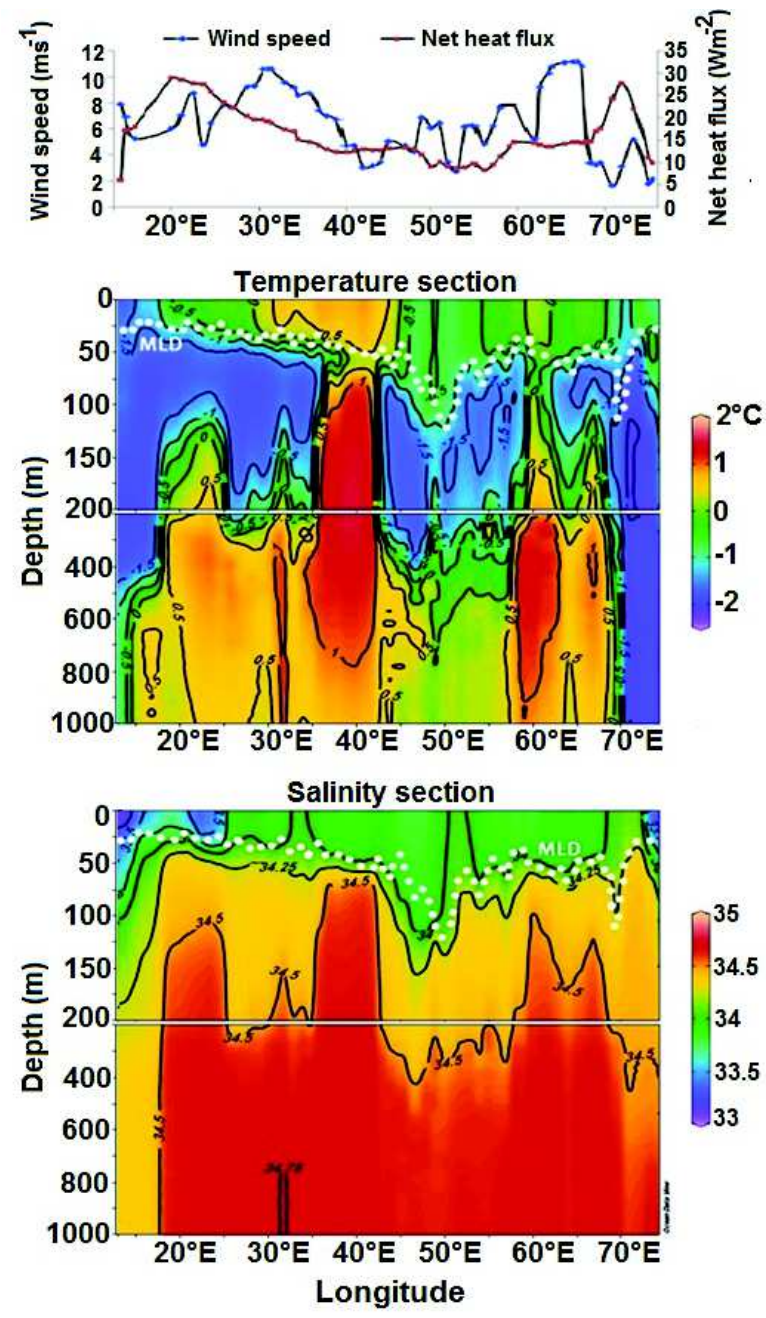

Fig. 4: Vertical temperature and salinity structures prepared from XCTD observations recorded during $19^{\text {th }}-25^{\text {th }}$ February, 2013. Mixed layer depth (represented by white dots) has been calculated as the depth where density change of $0.03 \mathrm{kgm}^{-3}$ is encountered from surface value (Dong et al., 2008). Surface meteorological parameters were derived from ECMWF interim forecast (Berrisford et al., 2011)

which is formed due the influence of the cyclonic circulation adjacent Amery Ice Shelf.

The thermal structure indicates two upwelling zones; one centered on $38^{\circ} \mathrm{E}$ and the other at $60^{\circ} \mathrm{E}$, which carries CDW to lower depths. India Bay and Prydz Bay experience strong downwelling whose signature is evident up to $1000 \mathrm{~m}$. These characteristic features of the two domains are influenced by Weddell Sea gyre and cyclonic gyre adjacent to the Amery Ice Shelf. We note that satellite chlorophyll-a images indicate high chlorophyll-a bloom in austral summer in the Prydz Bay promoted by strong stratification
Table 1: Criteria for identification of the principal water masses (after Smith and Tréguer, 1994)

\begin{tabular}{lcl}
\hline Water mass & $\theta\left({ }^{\circ} \mathrm{C}\right)$ & $S$ \\
\hline WW & -1.87 & 34.34 \\
CDW & 0.61 & 34.68 \\
CSW & -1.85 & 34.56 \\
Ice Shelf Water (ISW) & -2.00 & 34.50 \\
AABW & -0.51 & 34.66 \\
AASW & -1 to 1 & $34-34.6$ \\
\hline
\end{tabular}

resulting from melt water discharged from the Amery Ice Shelf, supplemented by net heat influx $(\sim 30$ $\mathrm{Wm}^{-2}$ ) into the ocean (Fig. 4).

\section{Conclusions}

In this preliminary study, the results pertaining to water masses and their distribution along a coastal section between Prydz Bay and the India Bay occupied during the austral summer of 2013 are discussed. A data set consisting of temperature and salinity profiles recorded by deploying XCTD has been used to highlight the principal water masses and the vertical thermohaline structure in the study area, and to elucidate the role of the Weddell Sea and cyclonic gyre adjacent to the Amery Ice Shelf and the possible role of surface meteorological parameters on the evolution of the vertical thermohaline structure. The data indicates that the Weddell Sea circulation promote a front at $40^{\circ} \mathrm{E}$ in the upper $400 \mathrm{~m}$, while influence of the cyclonic gyre adjacent to the Amery Ice Shelf promotes a front at $70^{\circ} \mathrm{E}$ which extends down to deeper depths. Deep mixed layer $(>100 \mathrm{~m})$ are encountered in conditions of weak wind speed. Signature of super cooled water was found in the Prydz Bay between 90-164 m. The profiles capture signatures of AABW at deeper depths $(>900 \mathrm{~m})$. CDW is the voluminous water mass that is detected in the study area.

\section{Acknowledgements}

The Ministry of Earth Sciences (MoES), Government of India, financed the XCTD probes deployed during the $32^{\text {nd }}$ Indian Scientific Expedition to Antarctica. We are grateful to Dr. Shailesh Nayak, former Secretary, MoES, for his support and encouragement to pursue this study. Former NCAOR Directors, Shri Rasik Ravindra and Dr. S. Rajan are acknowledged for making the facilities available for the research. 
We thank Shri. Mirza J. Beg, Project Director (Logistics), for extending the requisite logistics support for making the observations during the expedition. We thank two anonymous reviewers for their constructive comments on the earlier draft of this manuscript. This is NCAOR contribution 43/2016.

\section{References}

Anilkumar N, Mohan R, Shukla S K, Pednekar S M, Sudhakar M and Ravindra R (2010) Signature of coastal upwelling in Prydz Bay, East Antarctica during austral summer 2006 Current Science 99 1390-1394

Arrigo K R and Van Dijken G L (2003) Phytoplankton dynamics within 37 Antarctic coastal polynyas J Geophys Res $\mathbf{1 0 8}$ 3271 doi: 10.1029/2002JC001739

Arrigo K R, van Dijken G L and Bushinsky S (2008) Primary production in the Southern Ocean, 1997-2006 J Geophys Res 113 C08004, doi: 10.1029/2007JC004551

Bailey R, Gronell A, Phillips H, Meyers G and Tanner E (1993) CSIRO Cookbook for Quality Control of Expendable Bathythermograph (XBT) Data, CSIRO Marine Laboratories Report 221, CSIRO, Hobert

Berrisford P, Dee D P, Poli P, Brugge R, Fielding K, Fuentes M, Kållberg P W, Kobayashi S, Uppala S and Simmons A (2011) The ERA-Interim archive version 2.0. European Centre for Medium Range Weather Forecasts, Shinfield Park, Reading, Berkshire RG2 9AX, United Kingdom

Deacon G E R (1937) The hydrology of the Southern Ocean, Discovery Rep. 15, pp. 1-24, Inst. of Oceanogr. Sci., Southampton, UK

Dong S, J Sprintall, S T Gille and L Talley (2008) Southern Ocean mixed-layer depth from Argo float profiles J Geophys Res 113 C06013, doi: 10.1029/2006JC004051

Foster T D and Carmack E C (1976) Frontal zone mixing and Antarctic Bottom Water formation in the southern Weddell Sea Deep Sea Res 23 301-307

Gill A E (1973) Circulation and bottom water production in the Weddell Sea Deep Sea Res 20 111-140

Gordon AL (1998) Western Weddell Sea thermohaline stratification, ocean, ice, and atmosphere: interactions at the Antarctic continental margin Antarctic Research Series 75 215-240

Gordon A L, Zambianchi E, Orsi A, Visbeck M, Giulivi C F, Whitworth III T and Spezie G (2004) Energetic plumes over the western Ross Sea continental slope Geophys Res Letters 31 L21302 doi: 10.1029/2004GL020785

Heath R A (1985) A review of the physical oceanography of the seas around New Zealand - 1982 N Z J Mar Freshwater Res 19 79-124
Heywood K J, Naveira A C, Garabato D P, Stevens and Muench R D (2004) On the fate of the Antarctic Slope Front and the origin of the Weddell Front J Geophys Res 109 C06021 doi: 10.1029/2003JC002053

Iudicone D, Madec G, Blanke B and Specih S (2008) The role of Southern Ocean surface forcings and mixing in the global conveyor J Physical Oceanography 38 1377-1400

Jacobs S and Georgi D (1977) Observations on the southwest Indian/Antarctic Ocean Deep Sea Research 24 43-84

Jacobs S S (1991) On the nature and significance of the Antarctic Slope Front Mar Chem 35 9-24

Kizu S, Onishi H, Suga T, Hanawa K, Watanabe T and Iwamiya $\mathrm{H}$ (2008) Evaluation of the fall rates of the present and developmental XCTDs Deep-Sea Res Part 155 571-586

Middleton J H and Humphries S E (1989) Structure and mixing in the region of Prydz Bay Antarctica Deep-Sea Research 36 1255-1266

Mizuno K and Watanabe T (1998) Preliminary results of in situ XCTD/CTD comparison test J Oceanogr 54 373-380

Morris M, Stanton B R and Neil H L (2001) Subantarctic oceanography around New Zealand: Preliminary results from an ongoing survey $N Z J$ Mar Freshwater Res 35 499-519

Muench R D and Gordon A L (1995) Circulation and transport of water along the western Weddell Sea margin J Geophys Res 100 503-515 18

Orsi A H, Smethie Jr J and Bullister J L (2002) On the total input of Antarctic waters to the deep ocean: A preliminary estimate from chlorofluorocarbon measurements $J$ Geophysical Res 1073122 doi: 10.1029/2001JC000976

Orsi A H and Whitworth III T (2005) Hydrographic atlas of the World Ocean Circulation Experiment (WOCE). In: M. Sparrow, P. Chapman, \& J. Gould (Eds). Southern Ocean. International WOCE Project Office, Southampton, UK, vol. 1, ISBN 0-904175-49-9

Orsi A, Johnson G and Bullister J (1999) Circulation, mixing and production of Antarctic bottom water Progress Oceanography 43 55-109

Orsi A H, Whitworth III T and Nowlin W D Jr (1995) On the meridional extent and fronts of the Antarctic Circumpolar Current Deep Sea Res 42 641-673

Park Y-H, Charriaud E, Craneguy P and Kartavtseff A (2001) Fronts, transport, and Weddell Gyre at 30E between Africa and Antarctica J Geophys Res 106 2857-2879

Rintoul S R, Hughes C W and Olbers D (2001) The Antarctic Circumpolar Current system. In: G Siedler J, Church and J Gould (Eds). Ocean Circulation and Climate: Observing 
and Modelling the Global Ocean. Academic Press, London, pp. 271-302

Shi J, C Yaoyao, J Yutian and Jiaqiang H (2011) Supercooled water in austral summer in Prydz Bay, Antarctica Chinese Journal of Oceanology and Limnology 29 DOI: 10.1007/ s00343-010-0011-5

Smith N and P Tréguer (1994) Physical and chemical oceanography in the vicinity of Prydz Bay, Antarctica, In the Southern Ocean Ecology: The BIOMASS Perspective, S. Z. ElSayed, ed. Cambridge Uni. Press, Cambridge, pp 25-43

Smith N R, D Zhaoqian, K R Kerry and S Wright (1984) Water masses and circulation in the region of Prydz Bay, Antarctica Deep Sea Res 31 1121-1147

Sverdrup H U (1953) On conditions for the vernal blooming of phytoplankton. Journal du Conseil International pour l'Exploration de la Mer 18 287-295

Uchida H, Shimada K and Kawano T (2011) A method for data Processing to obtain high-quality XCTD data J Atmosph and Ocean Technol 28 816-826

Wakatsuchi M, K I Ohshima, M Hishida and M Naganobu (1994) Observations of a street of cyclonic eddies in the Indian
Ocean sector of the Antarctic Divergence J Geophys Res 99 417-20, 426

Withworth III, Orsi A H, Kim S-J, Nowlin Jr, W D and Locarnini R A (1998) Water masses and mixing near the Antarctic Slope Front. In: Jacobs, SS., Weiss, R.F. (Eds), Ocean, Ice and Atmosphere: Interactions at the Antarctic Continental Margin. AGU, Washington, DC, pp. 1-27

Wong A P S, Bindoff N L and Forbes A (1998) Ocean-ice shelf interaction and possible bottom water formation in Prydz Bay, Antarctica. In: Jacobs S S and Weiss R F (Eds.), Ocean, Ice and Atmosphere: Interactions at the Antarctic Continental Margin : Antarctic Research Ser 75. AGU, Washington D.C., pp. 173-187

Xiaojun Y, Douglas G M and Zhaoqian D (2004) Upper ocean thermohaline structure and its temporal variability in the southeast Indian Ocean Deep-Sea Res Part 151 333-347

Yabuki T, Suga T, Hanawa K, Matsuoka K, Jiwada H and Watanabe T (2006) Possible source of Antarctic Bottom Water in Prydz Bay region J Oceanography 62 649-655

Zeverev AA (1963) Currents in the Indian sector of the Antarctic Tr Sov Antarkt Eksped 17 144-155. 